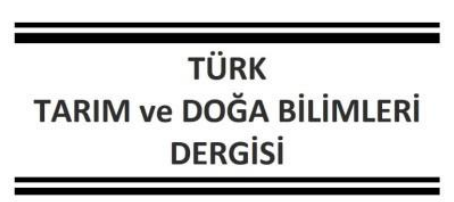

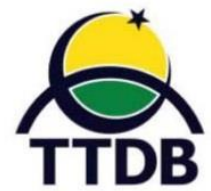

www.dergipark.gov.tr/turkjans

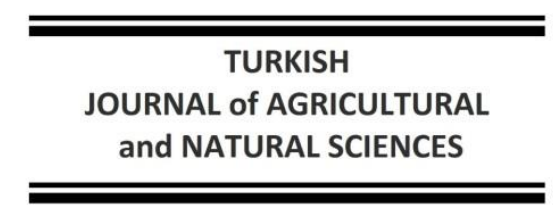

\title{
Araştırma Makalesi \\ Root System Interactions of Common Vetch (Vicia sativa L.) and Triticale
(Xtriticosecale Wittmack) Under Intercropping Conditions
}

Semih AÇIKBAŞ ${ }^{1}$, Mehmet Arif ÖZYAZICI ${ }^{1}$, Harun BEKTAŞ ${ }^{2 *}$

${ }^{1}$ Siirt University, Faculty of Agriculture, Department of Field Crops, Siirt

${ }^{2}$ Siirt University, Faculty of Agriculture, Department of Agricultural Biotechnology, Siirt

*Corresponding Author: bektasharun@gmail.com

Received: 15.01.2021 Received in revised: 11.05.2021 Accepted: 02.07.2021

\begin{abstract}
Intercropping, mixed cropping, and rotation are commonly applied and some of the oldest crop production techniques to improve soil structure and nitrogen status. While rotation takes generally two-season with one triticeae and legume, inter-and mixed cropping takes place within the same season. Among many advantages of legume inter-and mixed cropping, the most important one is the sustainable use of soil resources and reduced input cost. Numerous studies evaluated the effect of inter -and mixed cropping on above-ground interactions, very few investigated below-ground interactions in these systems. This study aimed to investigate common vetch (Vicia sativa) $\mathrm{x}$ triticale (Xtriticosecale Wittmack) root system interactions at the seedling stage under intercropping conditions. The study was conducted with a semi-hydroponic plexiglass system. Five different ratios were used to test species level intercommunication and competition. The results suggest that, while triticale significantly affected the development of common vetch roots, common vetch did not affect triticale. Triticale with a fibrous root system was more aggressive on root growth compared to common vetch. It was seen that the most vigorous root system development (for both species) was at doses with higher legume ratios. Our results highlight the importance of below-ground interactions for the selection of best ratios to gain maximum outcome from the intercropping systems.
\end{abstract}

Key words: Intercropping, root architecture, roots length, lateral root, root depth

\section{Karışım Ekim Koşullarında Yaygın Fiğ (Vicia sativa L.) ve Tritikale (Xtriticosecale Wittmack) Bitkisinin Kök Sistemi Etkileşimleri \\ $\overline{O ̈ z}$}

Karışım ekim, sıraya ekim ve rotasyon, toprak yapısınının iyileştirilmesi ve topraktaki azot durumunu artırmak için yaygın olarak uygulanan en eski üretim tekniklerindendir. Rotasyon, genellikle bir buğdaygil ve baklagil ile iki sezon sürerken, karışım ekim ve sıraya ekim ise bir sezonda yapılabilmektedir. Baklagil bitkilerinin karışım ekimde başlıca avantajları, toprak kaynaklarının sürdürülebilir kullanımı ve azaltılmış girdi maliyeti olarak sıralanabilir. Karışım ve sıraya ekim ile yapılan çalışmalarda, karışım ekimin toprak üstü bitki gelişime olan etkisi bir çok kez araştırılmış, sınırlı sayıda çalışmada ise, kök sistemi etkileşimlerinin incelendiği görülmüştür. Bu çalışmada, fide döneminde adi fiğ (Vicia sativa) x triticale (Xtriticosecale Wittmack) sıraya ekimlerinin detaylı kök sistemi etkileşimlerinin incelenmesi amaçlanmıştır. Çalışmada yarı hidroponik pleksiglas sistemi kullanılmıştır. Tür düzeyinde etkileşim ve rekabeti test etmek için beş farklı karışım oranı belirlenmiştir. Elde edilen sonuçlar, tritikalenin adi fiğ köklerinin gelişimini önemli ölçüde etkilediğini, adi fiğin ise tritikale'yi etkilemediğini göstermektedir. Saçak kök sistemine sahip olan tritikale, adi fiğ ile karşılaştırıldığında kök büyümesinde daha baskın bir gelişim göstermiştir. En iyi kök sistemi gelişiminin (her iki tür için) daha yüksek baklagil oranlarına sahip dozlarda olduğu görülmüştür. Elde edilen sonuçlar, karışım ekimden maksimum kazanç elde etmek için en iyi karışım ve sıraya ekim oranlarının belirlenmesi ve toprak altı etkileşimlerinin önemini vurgulamaktadır.

Anahtar kelimeler: Karışım ekim, kök mimarisi, kök uzunlukları, sekonder kök, kök derinliği 


\section{Introduction}

The leading source of balanced feeding in animal production is forage crops. Forage crops have a significant effect on erosion and soil improvement, especially for the soil with low organic matter content. Rotation, inter-and mixed cropping contributes to the nitrogen cycle and enhances soil quality (Kavut and Geren, 2017). These systemic practices also help to loosen the soil, improve soil structure, nitrogen, and organic matter content (Yıldırım and Özaslan Parlak, 2016; lqbal et al., 2019).

The cultivation of legume forage crops combined with cereals is one of the oldest agricultural practices (Mariotti et al., 2009; Lizarazo et al., 2020). The main reasons for farmers to prefer rotation, inter-and mixed cropping systems is to increase the forage yield and keep soil healthy with a sustainable approach (Ghanbari-Banjar and Lee, 2003; Deak et al., 2007; Lithourgidis and Dordas, 2010; Chen et al., 2019; Vidal et al., 2019). Legumes can also increase, available phosphorus (Bargaz et al., 2012) and the nutritional status of the plant (Contreras et al., 2019). They also allow low input production (Dai et al., 2019) and provide pest control without chemical pesticides (AllenPerkins and Estrada, 2019). Mixed cropping is reported to contribute to reduced weed infestation and increased water use efficiency (lqbal et al., 2019).

Inter-and mixed cropping systems may cause competition among neighboring plants for water, nutrients, and light (Lithourgidis et al., 2011). Unequal competition may reduce overall productivity, and one or the other side may be negatively affected in various aspects such as biomass, growth, or chemical compositions (Zoric et al., 2015). In grain and legume mixed cropping systems, sowing ratios of each cultivar or species may affect nitrogen supply and demand balance (Fan et al., 2019). Therefore, selection of the species and mixture ratios are key factors to obtain maximum sustainable benefit from the inter-and mixed cropping systems (Önal Aşcı and Eğritaş, 2017).

Although ecologists and agronomists considered spatial root distribution (architecture) of plants in the rhizosphere important for interspecies interactions in natural and agricultural ecosystems, very few empirical studies examined the root distribution dynamics and their effects on inter-species interactions ( Zhang et al., 2002; Zhang and Huang, 2003; Li et al., 2006). Maximum crop growth for biological or grain yield in inter-

and mixed cropping systems is significantly affected by the root distribution in the rhizosphere which determines water and nutrient uptake efficiency (Adiku et al., 2001). Önal Aşcı and Eğritaş (2017) reports that competition between plants depends on the mixture ratio. However, competition on roots and other root-to root interactions is still an unexplored field. Therefore, the objectives of this study were; (i) to evaluate seedling root architectural traits under controlled conditions in a common vetch and triticale intercropping system, (ii) to test root competition phenomenon between species at the seedling stage, and (iii) to obtain optimum mixture ratios, for minimum competition and maximum growth at the seedling stage.

\section{Materials and Methods}

The study was aimed to analyze the root system competition between triticale (Xtriticosecale Wittmack) x common vetch (Vicia sativa L.) intercropping system. The experiments were conducted in the Agricultural Biotechnology Laboratory, Faculty of Agriculture, Siirt University in April 2019. Triticale cultivar Karma 2000 and common vetch cv. Alper was selected to evaluate species-level interactions. The temperature ranges were between $25-27{ }^{\circ} \mathrm{C}$ and relative humidity was $60-70 \%$. The study was established according to the factorial design with 6 replications and 5 plants per replication.

Seeds were surface sterilized with $70 \%$ ethyl alcohol $\left(\mathrm{C}_{2} \mathrm{H}_{5} \mathrm{OH}\right)$ and $5 \%$ sodium hypochlorite $(\mathrm{NaClO})$ for 5 minutes in each. The sterilized seeds were rinsed under running water for 1 minute. The seeds were then imbibed in water for 24 hours to initiate homogeneous seed germination. Germinated seeds were placed in a plexiglass system consisting of two germination papers $(40 \times 40 \mathrm{~cm})$ as 5 seeds/germination paper. The entire system was covered with plexiglass plates and kept upright with a $45^{\circ}$ angle in a tub with a 15 $\mathrm{cm}$ water level. The experiment was completed at the end of the $15^{\text {th }}$ day.

Root images were obtained by separating plexiglass plates and scanning each plant with a handheld scanner (Iscan Color Mini Portable Scanner) at 600 DPI resolution. Root images were analyzed using ImageJ (imagej.nih.gov; Rueden et al., 2017) image analysis software. Legume and grains were tested in five different ratios; $100 \%$ common vetch (100V), 100\% triticale (100T), 50\% common vetch and $50 \%$ triticale (50V-50T), $80 \%$ common vetch, and $20 \%$ triticale (80V-20T), and $20 \%$ common vetch and $80 \%$ triticale (80T-20V). The names, abbreviations, and references for the traits are given in Table 1.

Statistical analysis was performed using Statistix software v10 (Analytical Software; 
Tallahassee, FL, USA) to measure the variation between and within the species. The Least Significant Difference (LSD) multi comparison test was applied for species, and mixture ratios (Steel et al., 1997). A comparative analysis was made between $100 \%$ common vetch and intercropping for the number of roots and root lengths at depth zones of $0-5,5-10,10-15$, and $15+\mathrm{cm}$. The ratio of change was calculated as the percent value of intercropping (50V-50T, 80V-20T, and 80T-20V) in $100 \%$ common vetch (100V).

Table 1. The names, abbreviations, and related references for the investigated root traits

\begin{tabular}{|c|c|c|}
\hline Abbreviation & Trait Name & References \\
\hline NOR & number of roots & $\begin{array}{l}\text { Mia et al., 1996; Ceritoglu et al., 2020; } \\
\text { Acikbas et al., } 2021\end{array}$ \\
\hline NLR & number of lateral roots & $\begin{array}{l}\text { Lynch and van Beem, 1993; Orman-Ligeza } \\
\text { et al., 2014; }\end{array}$ \\
\hline LRL & longest root length & Kashiwagi et al., 2015; Bektas, 2021. \\
\hline TRL & total roots length & $\begin{array}{l}\text { Lynch and van Beem, 1993; Orman-Ligeza } \\
\text { et al., } 2014\end{array}$ \\
\hline TLRL & total lateral roots length & Mia et al., 1996; Ye et al., 2018 \\
\hline NOR $0-5$ & total number of roots at $0-5 \mathrm{~cm}$ & \multirow{8}{*}{$\begin{array}{l}\text { Orman-Ligeza et al., 2014; Chen et al., } \\
2017\end{array}$} \\
\hline RL 0-5 & lengths of roots at $0-5 \mathrm{~cm}$ & \\
\hline NOR 5-10 & total number of roots at $5-10 \mathrm{~cm}$ & \\
\hline $\mathrm{RL} 5-10$ & lengths of roots at $5-10 \mathrm{~cm}$ & \\
\hline NOR $10-15$ & total number of roots at $10-15 \mathrm{~cm}$ & \\
\hline $\mathrm{RL} 10-15$ & lengths of roots at $10-15 \mathrm{~cm}$ & \\
\hline NOR 15+ & total number of roots at $15+\mathrm{cm}$ & \\
\hline $\mathrm{RL} 15+$ & lengths of roots at $15+\mathrm{cm}$ & \\
\hline
\end{tabular}

\section{Results and Discussion}

The effect of intercropping system in root system development and interactions on common vetch and triticale were evaluated at the seedling stage. In this study, the importance of the seeding rate in the seedling growth was discussed. There were no previous reports evaluating root system interactions in a multi-species root system analysis platform. According to the results, the roots of triticale significantly affect common vetch roots. Understanding the underlying physiological processes and mechanism of action is considered to be the main challenge for inter-and mixed cropping systems and rhizosphere dynamics (Brooker et al., 2015; Novoplansky, 2019). In the study, root developments of two species under five different ratios (100V, 100T, 80T-20V, 80V-20T, and 50T-50V) were evaluated, and the root competition phenomenon was investigated.

Root growth parameters of NOR, NLR, LRL, TRL, TLRL, NOR0-5, NOR5-10, RL5-10, NOR10-15, RL10-15, NOR15 +, and RL15 + were analyzed. Intercropping (50V-50T, 80T-20V, 80V-20T,) showed significant $(p<0.01)$ differences in the root number, distribution, and length parameters compared to $100 \mathrm{~T}$ or $100 \mathrm{~V}$. It has been determined that common vetch and triticale roots are affected by the presence of another species in the same environment. Previous reports suggest that legume and grain inter-and mixed cropping affect root biomass, architecture, and development (CorreHellou and Crozat, 2005; Li et al., 2006; Zuo and Zhang, 2008; Xia et al., 2013; Streit et al., 2019).

\section{The Effect of Intercropping on Common Vetch Root Architecture}

Root to root interactions was evaluated from the common vetch perspective. While the highest value (17.95 per plant) for NOR in triticalecommon vetch intercropping were in the $100 \mathrm{~V}$, common vetch in the 50V-50T and $80 \mathrm{~V}-20 \mathrm{~T}$ ratios had similar values according to LSD analysis (Table 2 ). When common vetch growth in $100 \mathrm{~V}$ is compared with the growth in other ratios, it was seen that the NOR value of the common vetch in the intercropping was lower than 100V. The presence of triticale is thought to have a negative effect on the root development of common vetch. In cases where the common vetch ratio was equal or more than triticale (80V-20T and 50V-50T), common vetch development was sufficient despite triticale, on the other hand when the common vetch ratio was lower than the triticale ratio (80T$20 \mathrm{~V})$, root development of the common vetch was more suppressed (Table 2 ).

The number of lateral roots (NLR) was calculated for common vetch, while only the 
number of roots (NOR) was calculated for triticale. The highest value (16.93 per plant) for NLR was determined in the $100 \mathrm{~V}$. The difference between the common vetch values planted in $100 \mathrm{~V}$, 50V-50T (15.14 per plant), and 80V-20T (14.04 per plant) was not significant.

Common vetch TRL values varied between 37.45 and $49.98 \mathrm{~cm}$. While the highest TRL value was observed in the 80V-20T ratio, the lowest value was found in the common vetch in the 80T$20 \mathrm{~V}$ ratio (Table 2 ). While triticale forms few seminal roots, vetch is a species with advanced lateral root development. Therefore, lateral root development in common vetch is more likely to be affected by the presence of another crop. The effect of triticale was seen in the lateral root lengths. Higher ratios of triticale seem to limit lateral root lengths compared to $100 \mathrm{~V}$. This might be due to strong competition of triticale compared to legumes due to their relatively quick root initiation, large root size, and deeper root distribution (Gregory et al., 1995; Gregory and Eastham, 1996; Hauggaard-Nielsen et al., 2001).

The effect of intercropping on the TLRL was not significant for common vetch. The highest value was obtained as $29.24 \mathrm{~cm}$ in $100 \mathrm{~V}$ and the lowest was found in $80 \mathrm{~T}-20 \mathrm{~V}$ mixture as $16.90 \mathrm{~cm}$ (Table 2). When the common vetch intercropping ratios were compared for NLR, it can be said that common vetch planted in $100 \mathrm{~V}$ showed better root development compared to those planted in the mixture.

Table 2. Mean values of root traits for common vetch and triticale under monocropping and intercropping conditions in a semi-hydroponics plexiglass system

\begin{tabular}{lllllll}
\hline & Mixture ratio & NOR & NLR & LRL (cm) & TRL (cm) & TLRL (cm) \\
\hline \multirow{2}{*}{$\begin{array}{lllll}\text { Common } \\
\text { vetch }\end{array}$} & 100V & $17.95 \mathrm{a}$ & $16.93 \mathrm{a}$ & 20.12 & $49.36 \mathrm{bc}$ & 29.24 \\
& 50V+50T & $16.25 \mathrm{ab}$ & $15.14 \mathrm{ab}$ & 20.71 & $48.87 \mathrm{bc}$ & 28.16 \\
& 80T+20V & $11.42 \mathrm{~b}$ & $10.23 \mathrm{~b}$ & 20.55 & $37.45 \mathrm{c}$ & 16.90 \\
\hline \multirow{2}{*}{ Triticale } & 100T & $3.95 \mathrm{c}$ & $\mathrm{NA}$ & 27.93 & $76.34 \mathrm{a}$ & $\mathrm{NA}$ \\
& 50V+20T & $3.27 \mathrm{c}$ & $\mathrm{NA}$ & 25.72 & $52.94 \mathrm{bc}$ & $\mathrm{NA}$ \\
& 80T+20V & $3.63 \mathrm{c}$ & $\mathrm{NA}$ & 23.05 & $54.16 \mathrm{bc}$ & $\mathrm{NA}$ \\
\hline F value & $4.13 \mathrm{c}$ & $\mathrm{NA}$ & 24.80 & $60.86 \mathrm{~b}$ & $\mathrm{NA}$ \\
\hline
\end{tabular}

Means followed by different letters within columns are different according to least significant difference test, $* *: p<0.01, \mathrm{NA}:$ Not applicable, ns: not significant, NOR: number of roots, NLR: number of lateral roots, LRL: longest root length, TRL: total root length, TLRL: total lateral root lengt

To evaluate the effect of intercropping on rooting ability in depth zones of $0-5,5-10,10-15$, and $15+\mathrm{cm}$ (Fig. 1-2.), the number and lengths of roots in each zone was calculated. Common vetch roots had a decrease in all depth zones due to the increasing triticale ratio and common vetch in $80 \mathrm{~T}$ $20 \mathrm{~V}$ had the lowest number and lengths of lateral roots (Fig. 1). There was a 45 to $100 \%$ reduction in lateral root lengths in the $80 \mathrm{~T}-20 \mathrm{~V}$ ratio in depth zones compared to $100 \mathrm{~V}$. Similarly, the number of lateral roots in common vetch decreased between 18.45 to $100 \%$ in depth zones (Table 3).

Total root lengths of 50V-50T at RL5-10 depth zone and $80 \mathrm{~V}-20 \mathrm{~T}$ at RL10-15 depth zone were 68.60 and $33.03 \%$ longer than root lengths at $100 \mathrm{~V}$, respectively (Fig. 2. and Table 3 ). According to results obtained in triticale $x$ common vetch intercropping trials, there was a negative correlation between the ratio of triticale and root development of common vetch at various rooting depth zones. Triticale seems to suppress or compete with the roots of common vetch (Acar et al., 2006). The reasons may be various and may need in-depth physiological and molecular analysis to uncover the mechanism.

\section{The Effect of Intercropping on Triticale Root Architecture}

The highest value for the NOR in triticale was obtained in the $80 \mathrm{~T}-20 \mathrm{~V}$ ratio with 4.13 roots per plant and the lowest value was in 80V-20T with 3.27 per plant (Table 2). Triticale did not show any significant difference between control (100T) and intercropping ratios. It constituted the lowest group in terms of NOR, including all mixtures and $100 \mathrm{~T}$ plantings, which is expected due to the fibrous rooting nature of triticale compared to tap 
and lateral roots in common vetch. When the effect of intercropping with legumes evaluated for the NOR in triticale, it was seen that legumes did not limit triticale root growth (Table 2). The NLR and TLRL parameters were not taken into consideration for triticale since these traits are only related to taproot systems. It was determined that the TRL values of the triticale varied between 52.94 (80V-20T) and $76.34 \mathrm{~cm}$ (100T) per plant. Triticale in the $80 \mathrm{~T}-20 \mathrm{~V}, 50 \mathrm{~V}-50 \mathrm{~T}$, and $80 \mathrm{~V}-20 \mathrm{~T}$ intercropping were statistically in the same group and formed the second group after 100T (Table 2). Intercropping seems to affect TRL in triticale, but it was not a strong effect to consider or the results of this study were biased due to genotype or other factors.

\section{Intercropping Competition}

The fibrous root structure of triticale developed faster than common vetch in the seedling stage. As previously reported, the root growth of cereal grains normally exceeds that of legumes (Gregory et al., 1995; Turpin et al., 2002). Cereals also do not show a clear advantage over legumes in terms of relative shoot or root yield (Streit et al., 2019). Seedling development of perennial forage plants may be slower and weaker compared to annual cereals at the early growth stages. Therefore, the competitiveness of these seedlings against weeds, especially monocotyledons, may be slow. The seedlings of perennial legumes generally form a few leaves and use resources to develop a root system. At this stage, weeds may compete for water and minerals,

leading to yield losses (Acar et al., 2006). In these and similar cases, an annual plant that can compete with weeds (biological control) as a friendly plant and that can bring income in the first year might be selected (Tan and Serin, 2004). Abdel et al. (1991) reported alfalfa (Medicago sativa) and wheat cropping to increase the yield and quality of wheat and protect it from the winter colds. They determined that the grain yield of wheat increased by $130-160 \mathrm{~kg}$ da-1 in mixed cropping plots, while the crude protein ratio and biomass yield of alfalfa were also increased. It is widely known that legumes support neighboring non-legume plants through nitrogen fixation. However, sharing the nitrogen with other species may cause the risk of not meeting its own nitrogen needs. Therefore, it is important to determine the ratio of non-leguminous species in the mixture for the highest grain yield and biomass production.

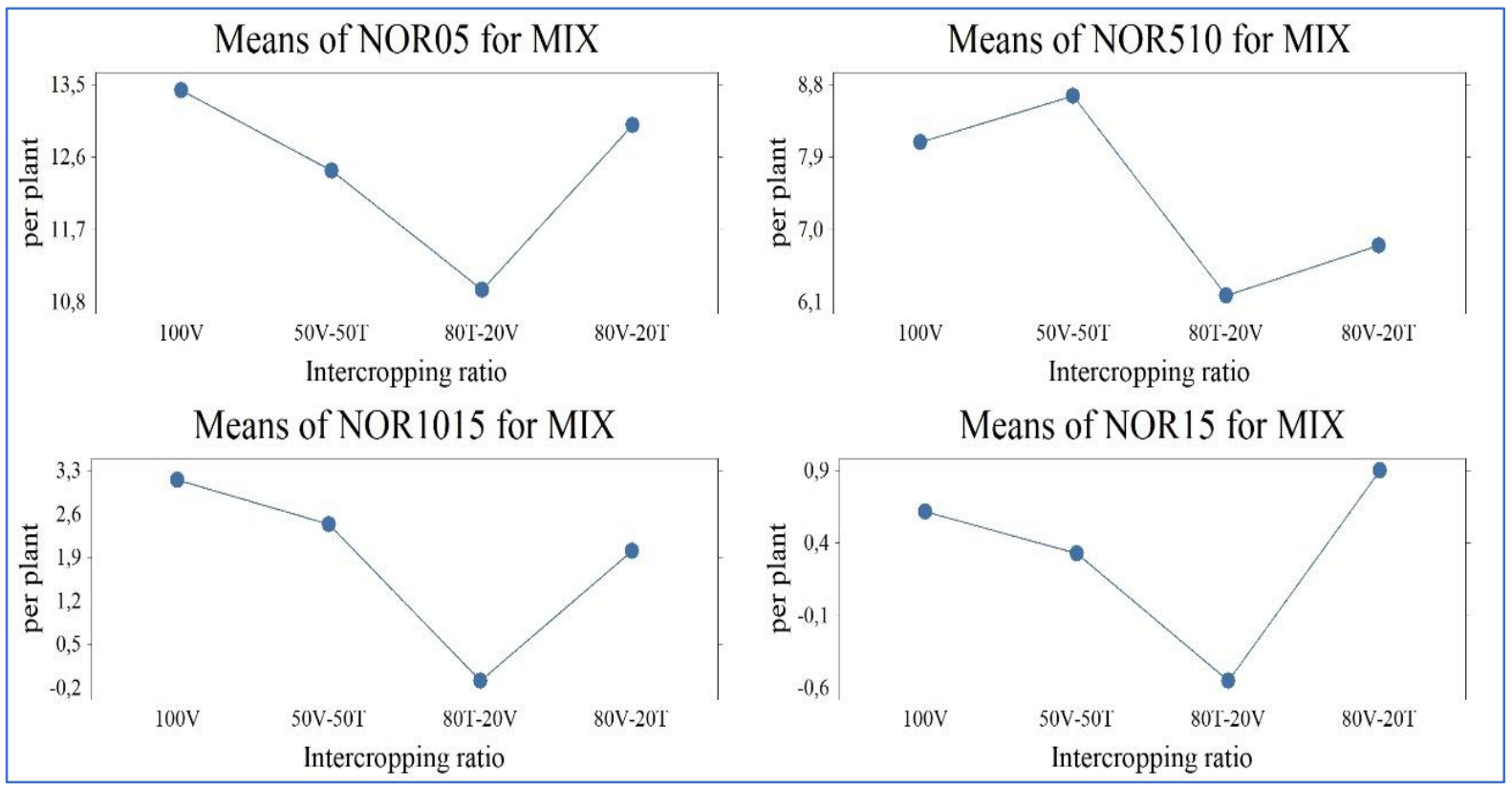

Figure 1. Mean values of number of roots (NOR) at depth zones for common vetch under monocropping and intercropping conditions in a semi-hydroponics plexiglass system 


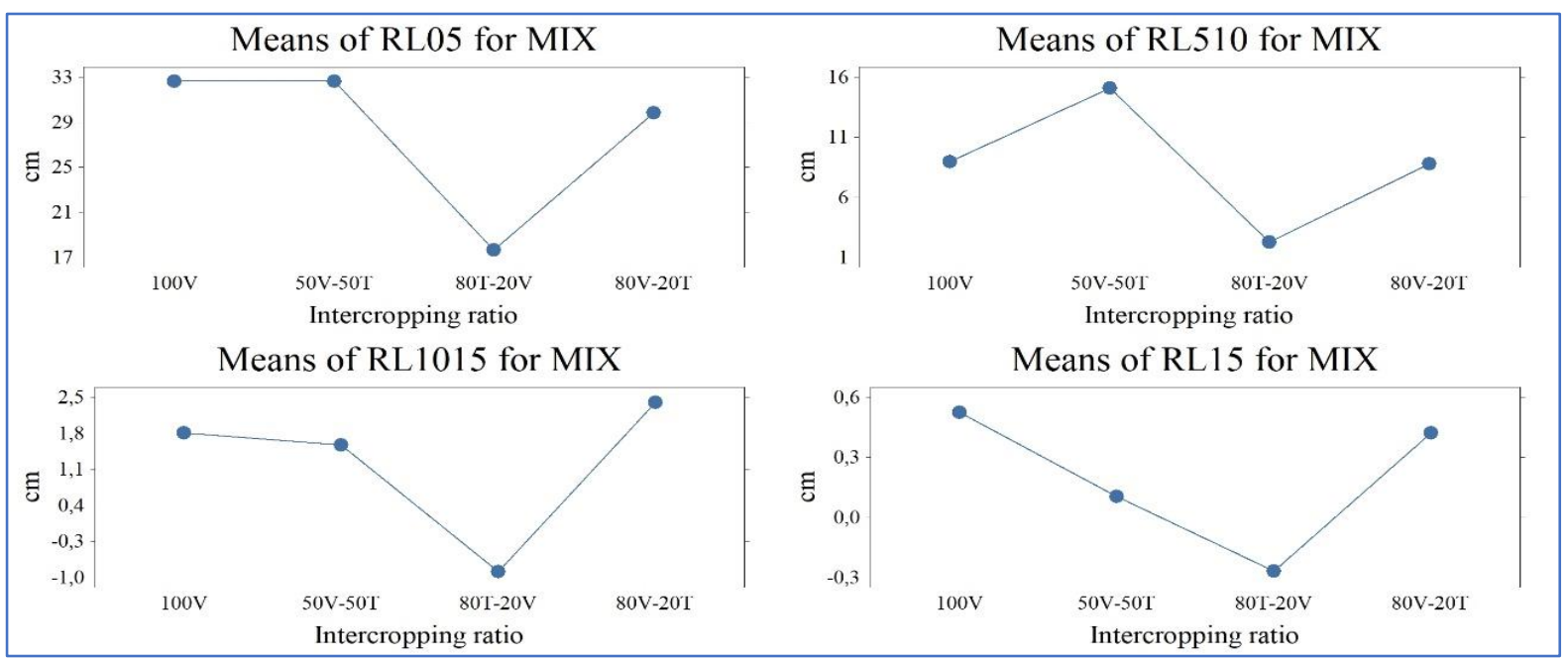

Figure 2. Mean values of total root length (RL) at depth zones for common vetch under monocropping and intercropping conditions in a semi-hydroponics plexiglass system

Table 3. Comparisons of root traits for common vetch under inter- and monocropping conditions

\begin{tabular}{|c|c|c|c|c|c|}
\hline \multicolumn{3}{|c|}{ Means of RL 0-5 cm } & \multicolumn{3}{|c|}{ Means of NOR 0-5 cm } \\
\hline Mixture ratio & Mean SE & Dif. (\%) & Mixture ratio & Mean & Dif. (\%) \\
\hline $100 \mathrm{~V}$ & $32.62 \pm 6.26$ & 0.00 & $100 \mathrm{~V}$ & $13.43 \pm 1.74$ & 0.00 \\
\hline 80V-20T & $29.82 \pm 4.60$ & 8.59 & $80 \mathrm{~V}-20 \mathrm{~T}$ & $13.00 \pm 1.28$ & 3.19 \\
\hline 50V-50T & $32.62 \pm 6.26$ & 0.02 & 50V-50T & $12.43 \pm 1.74$ & 7.45 \\
\hline $80 \mathrm{~T}-20 \mathrm{~V}$ & $17.65 \pm 6.78$ & 45.91 & 80T-20V & $10.95 \pm 1.88$ & 18.45 \\
\hline \multicolumn{3}{|c|}{ Means of RL $5-10 \mathrm{~cm}$} & \multicolumn{3}{|c|}{ Means of NOR 5-10 cm } \\
\hline Mixture ratio & Mean SE & Dif. (\%) & Mixture ratio & Mean & Dif. (\%) \\
\hline $100 \mathrm{~V}$ & $8.94 \pm 3.06$ & 0.00 & $100 \mathrm{~V}$ & $8.09 \pm 1.71$ & 0.00 \\
\hline 80V-20T & $8.77 \pm 2.24$ & 1.91 & 80V-20T & $6.80 \pm 1.26$ & 15.90 \\
\hline 50V-50T & $15.07 \pm 3.06$ & -68.60 & 50V-50T & $8.66 \pm 1.71$ & -7.07 \\
\hline $80 \mathrm{~T}-20 \mathrm{~V}$ & $2.26 \pm 3.31$ & 74.74 & 80T-20V & $6.18 \pm 1.85$ & 23.56 \\
\hline \multicolumn{3}{|c|}{ Means of RL 10-15 cm } & \multicolumn{3}{|c|}{ Means of NOR $10-15 \mathrm{~cm}$} \\
\hline Mixture ratio & Mean SE & Dif. (\%) & Mixture ratio & Mean & Dif. (\%) \\
\hline $100 \mathrm{~V}$ & $1.81 \pm 1.47$ & 0.00 & $100 \mathrm{~V}$ & $3.14 \pm 1.45$ & 0.00 \\
\hline 80V-20T & $2.40 \pm 1.08$ & -33.03 & $80 \mathrm{~V}-20 \mathrm{~T}$ & $2.00 \pm 1.07$ & 36.36 \\
\hline 50V-50T & $1.57 \pm 1.47$ & 12.92 & 50V-50T & $2.43 \pm 1.45$ & 22.73 \\
\hline 80T-20V & $0.21 \pm 1.59$ & 88.37 & 80T-20V & $0.67 \pm 1.57$ & 78.68 \\
\hline \multicolumn{3}{|c|}{ Means of RL 15+ cm } & \multicolumn{3}{|c|}{ Means of NOR $15+\mathrm{cm}$} \\
\hline Mixture ratio & Mean SE & Dif. (\%) & Mixture ratio & Mean SE & Dif. (\%) \\
\hline $100 \mathrm{~V}$ & $0.52 \pm 0.51$ & 0.00 & $100 \mathrm{~V}$ & $0.61 \pm 0.85$ & 0.00 \\
\hline 80V-20T & $0.42 \pm 0.37$ & 19.49 & 80V-20T & $0.90 \pm 0.63$ & -46.51 \\
\hline 50V-50T & $0.10 \pm 0.51$ & 80.39 & 50V-50T & $0.33 \pm 0.85$ & 46.51 \\
\hline 80T-20V & $0.00 \pm 0.00$ & 100.00 & $80 \mathrm{~T}-20 \mathrm{~V}$ & $0.00 \pm 0.00$ & 100.00 \\
\hline
\end{tabular}

RL: Root length, NOR: Number of roots, SE: Standard error, Dif: Difference

\section{Conclusion}

This study evaluated the seedling root architectures of common vetch and triticale under monocropping and various intercropping ratios. The competition and inter-species interactions of root systems at the seedling stage are revealed in this preliminary study. According to our observations, triticale had a negative effect on the root development of common vetch, while triticale was not affected by the common vetch. The results highlight the value of the topic and there is a need for in-depth evaluations with further species.

Conflict of Interest Statement: The manuscript's authors declare that they do not have any conflict of interest.

Researchers' Contribution Rate Statement Summary: All authors contributed equally to the manuscript. 


\section{References}

Abd-El-Samie, F.S. 1994. Growth and yield of maize as affected by $\mathrm{N}$-levels and preceding winter crops. Annals of Agricultural Science, 39(2): 623-631.

Abdel Magid, H.M., Ghoneim, M.F., Rabie, R.K. and Sabrah, R.E. 1991. Productivity of wheat and alfalfa under intercropping. Experimental Agriculture, 27(4):391-395.

Acar, Z., Önal Aşcı, Ö., Ayan, I.., Mut, H. and Başaran, U. 2006. Intercropping systems for forage crops. Anadolu Journal of Agricultural Sciences, 21(3): 379-386. (In Turkish).

Acikbas, S., Ozyazici, M.A. and Bektas, H. 2021. The effect of salinity on root architecture in forage pea (Pisum sativum ssp. arvense L.). Legume Research- An International Journal, 44(4): 407-412.

Adiku, S.G.K., Ozier-Lafontaine, H. and Bajazet, T. 2001. Patterns of root growth and water uptake of a maize-cowpea mixture grown under greenhouse conditions. Plant Soil, 235: 85-94.

Allen-Perkins, A., Estrada, E. 2019. Mathematical modelling for sustainable aphid control in agriculture via intercropping. Proceedings of the Royal Society A, 475.2226: 20190136.

Bargaz, A., Faghire, M., Abdi, N., Farissi, M., Sifi, B., Drevon, J. J. and Ghoulam, C. 2012. Low soil phosphorus availability increases acid phosphatases activities and affects $P$ partitioning in nodules, seeds and rhizosphere of Phaseolus vulgaris. Agriculture, 2(2): 139-153.

Bektas, H. 2021. The effect of salt stress on root development and architecture in common grasspea (Lathyrus sativus L.). European Journal of Science and Technology, (23): 793-799.

Brooker, R.W., Bennett, A.E., Cong, W.F., Daniell, T.J., George, T.S., Hallett, P.D., Hawes, C., lannetta, P.P.M., Jones, H.G., Karley, A.J., Li, L., McKenzie, B.M., Pakeman, R.J., Paterson, E., Schöb, C., Shen, J., Squire, G., Watson, C.A., Zhang, C., Zhang, F., Zhang, J. and White, P.J. 2015. Improving intercropping. A synthesis of research in agronomy, plant physiology and ecology. New Phytologist, 206(1):107-117.

Ceritoglu, M., Ceritoglu, F., Erman, M. and Bektas, H. 2020. Root system variation of pulse crops at early vegetative stage. Notulae Botanicae Horti Agrobotanici Cluj-Napoca, 48(4): 2182-2197.

Chen, Y., Ghanem, M.E. and Siddique, K.H.M. 2017. Characterizing root trait variability in chickpea (Cicer arietinum L.) germplasm. Journal of Experimental Botany, 68(8):19871999.

Chen, P., Song, C., Liu, X.M., Zhou, L., Yang, H., Zhang, X. and Wang, X.C. 2019. Yield advantage and nitrogen rate in an additive maize-soybean relay intercropping system. Science of the Total Environment, 657: 987999.

Contreras, F., Díaz, J., Rombolà, A.D. and De La Luz Mora, M. 2019. Prospecting intercropping between subterranean clover and grapevine as potential strategy for improve grapevine performance. Current Plant Biology, 19:100110.

Corre-Hellou, G. and Crozat, Y. 2005. Assessment of root system dynamics of species grown inmixtures under field conditions using herbicide injection and $15 \mathrm{~N}$ natural abundance methods: a case study with pea, barley and mustard. Plant Soil, 276(12):177-192

Dai, J., Qiu, W., Wang, N., Wang, T., Nakanishi, H. and Zuo, Y.M. 2019. From Leguminosae/Gramineae intercropping systems to see benefits of intercropping on iron nutrition. Frontiers in Plant Science, 10: 605.

Deak, A., Hall, M.H., Sanderson, M.A. and Archibadl, D.D. 2007. Production and nutritive value of grazed simple and complex forage mixtures. Agronomy Journal, 99: 814-821.

Demiroğlu Topçu, G., Kır, B., Çelen, A. E. and Kavut, Y.T. 2020. Investigations on the Herbage and some other charateristics of common vetch cereal mixtures of different harvest dates. ISPEC Journal of Agricultural Sciences, 4(2): 146-156. (In Turkish).

Fan, Z., Zhao, Y., Chai, Q., Zhao, C., Yu, A., Coulter, J.A. and Cao, W. 2019. Synchrony of nitrogen supply and crop demand are driven via high maize density in maize/pea strip intercropping. Scientific Reports, 9(1):1-14.

Ghanbari-Banjar, A. and Lee, H.C. 2003. Intercropped wheat (Triticum aestivum L.) and bean (Vicia faba L.) as a whole crop forage: effect of harvest time on forage yield and quality. Grass and Forage Science, 58:28-36.

Gregory, P.J., Palta, J.A. and Batts, G.R. 1995. Root systems and root: mass ratio-carbon allocation under current and projected atmospheric conditions in arable crops. Plant Soil, 187(2): 221-228.

Gregory, P.J. and Eastham, J. 1996. Growth of shoots and roots, and interception of 
radiation by wheat and lupin crops on a shallow, duplex soil in response to time of sowing. Australian Journal of Agricultural Research, 47(3):427-447.

Haugland, E. and Tawfiq, M. 2001. Root and shoot competition between established grass species and newly sown seedlings during spring growth. Grass and Forage Science, 56(2): 193-199.

Hauggaard-Nielsen, H., Ambus, P. and Jensen, E.S. 2001. Temporal and spatial distribution of roots and competition for nitrogen in peabarley intercrops a field study employing 32P technique. Plant Soil, 236(1):63-74.

Horner, A., Browett, S.S. and Antwis, R.E. 2019. Mixed-cropping Between field pea varieties alters root bacterial and fungal communities. Scientific Reports, 9(1): 1-10.

Iqbal, M.A., Hamid, A., Ahmad, T., Siddiqui, M.H., Hussain, I., Ali, S. and Ahmad, Z. 2019. Forage sorghum-legumes intercropping: effect on growth, yields, nutritional quality and economic returns. Bragantia, 78(1): 8295.

Kavut, Y.T. and Geren, H. 2017. Effects of different harvest dates and mixture rates on the yield and some silage quality characteristics of legume mixtures with annual ryegrass (Lolium multiflorum L.). Journal of Agriculture Faculty of Ege University, 54(2): 115-124. (In Turkish).

Kashiwagi, J., Krishnamurthy, L., Purushothaman, R., Upadhyaya, H.D., Gaur, P.M., Gowda, C.L.L. and Varshney, R.K. 2015. Scope for improvement of yield under drought through the root traits in chickpea (Cicer arietinum L.). Field Crops Research, 170:4754.

Li, L., Sun, J., Zhang, F., Guo, T., Bao, X., Smith, A. and Smith, S.E. 2006. Root distribution and interactions between intercropped species. Oecologia, 147: 280-290.

Lithourgidis, A.S.and Dordas, C.A. 2010. Forage yield, growth rate, and nitrogen uptake of faba bean intercrops with wheat, barley, and rye in three seeding ratios. Crop Science, 50(5): 2148-2158.

Lithourgidis, A.S., Dordas, C.A., Damalas, C.A. and Vlachostergios, D.N. 2011. Annual intercrops: an alternative pathway for sustainable agriculture. Australian Journal of Crop Science, 5:396-410.

Lynch, J.P. and van Beem, J.J. 1993. Growth and architecture of roots of common bean genotypes. Crop Science, 5(6):1253-1257.

Mariotti, M., Masoni, A., Ercoli, L. and Arduini, I. 2009. Above and below ground competition between barley, wheat, lupin and vetch in a cereal and legume intercropping system. Grass and Forage Science. 64: 401-412.

Mia, M.W., Yamauchi, A. and Kono, Y. 1996. Root system structure of six food legume species: Inter and Intraspecific variations. Japanese Journal of Crop Science, 65(1): 131-140.

Novoplansky, A. 2019. What plant roots know? Seminars in Cell \& Developmental Biology, 92: 126-133.

Orman-Ligeza, B., Civava, R., Dorlodot, S. and Draye, X. 2014. Root system architecture. Root Engineering: Basic and Applied Concepts. In: Morte A, Varma A (Eds), Springer Heidelberg, New York.

Önal Aşcl, Ö. and Eğritaş, Ö. 2017. Determination of forage yield, some quality properties and competition in common vetch-cereal mixtures. Journal of Agricultural Sciences, 23:242-252. (In Turkish).

Önal Aşcı, Ö., Demirkol, G. and Kaşko Arıcı, Y. 2020. Evaluation of hay yield, quality and interspecies competition in hungarian vetch-rapeseed mixtures. Academic Journal of Agriculture, 9(1): 119-128. (In Turkish).

Rueden, C.T., Schindelin, J. and Hiner, M.C. 2017. ImageJ2: ImageJ for the next generation of scientific image data, BMC Bioinformatics, 18:529.

Seydoşoğlu, S., Gelir, G. and Çam, B.A. 2020. Effects of mixture ratio and harvest periods on yield of forage pea and triticale mixtures. Adnan Menderes University Faculty of Agriculture Journal, 17(1): 9-13. (In Turkish).

Steel, R.G.D., Torrie, J.H. and Dickey, D.A. 1997. Principles and Procedures of Statistics: $a$ Biometrical Approach. McGraw-Hill, New York.

Streit, J., Meinen, C., Nelson, W.C.D., SiebrechtSchöll, D.J. and Rauber, R. 2019. Above-and belowground biomass in a mixed cropping system with eight novel winter faba bean genotypes and winter wheat using FTIR spectroscopy for root species discrimination. Plant and Soil, 436(1-2): 141158.

Tan, M. and Serin, Y. 2004. Is the companion crop harmless to alfalfa establishment in the highlands of east Anatolia? Journal of Agronomy and Crop Science, 190(1): 1-5.

Turpin, J.E., Herridge, D.F. and Robertson, M.J. 2002. Nitrogen fixation and soil nitrate interactions in field-grown chickpea (Cicer arietinum) and faba bean (Vicia faba). Australian Journal of Agricultural Research, 53(5): 599-608. 
Vidal, D.F., Trichet, P., Puzos, L., Bakker, M.R., Delerue, F. and Augusto, L. 2019. Intercropping $\mathrm{N}$-fixing shrubs in pine plantation forestry as an ecologically sustainable management option. Forest Ecology and Management, 437: 175-187.

Xia, H.Y., Zhao, J.H., Sun, J.H., Bao, X.G., Christie, P., Zhang, F.S. and Li, L. 2013. Dynamics of root length and distribution and shoot biomass of maize as affected by intercropping with different companion crops and phosphorus application rates. Field Crops Research, 50:52-62.

Ye, H., Roorkiwal, M., Valliyodan, B., Zhou, L., Chen, P., Varshney, R.K. and Nguyen, H.T. 2018. Genetic diversity of root system architecture in response to drought stress in grain legumes. Journal of Experimental Botany, 69(13): 3267-3277.

Yıldırım, S. and Özaslan Parlak, A. 2016. Forage yield, qualty of triticale intercrops with faba bean, pea and vetch at varying seeding ratios. COMU Journal of Agriculture Faculty, 4(1): 77-83. (In Turkish).

Zhang, E. and Huang, G. 2003. Temporal and spatial distribution characteristics of the crop root in intercropping system. Ying Yong Sheng Tai Xue Bao= The Journal of Applied Ecology, 14(8): 1301-1304.

Zhang, E., Li, L., Huang, G., Huang, P. and Chai, Q. 2002. Regulation of fertilizer application on yield and root growth of spring wheat-faba bean intercropping system. Ying Yong Sheng Tai Xue Bao= The Journal of Applied Ecology, 13(8): 839-842.

Zoric, L., Mikic, A., Antanasovic, S., Karanovic, D., Cupina, B. and Lukovic, J. 2015. Stem anatomy of annual legume intercropping components: white lupin (Lupinus albus L.), narbonne (Vicia narbonensis L.) and common (Vicia sativa L.) vetches. Agricultural and Food Science, 24(2): 139149.

Zuo, Y. and Zhang, F. 2008. Effect of peanut mixed cropping with gramineous species on micronutrient concentrations and iron chlorosis of peanut plants grown in a calcareous soil. Plant and Soil, 306(1-2): 2336. 